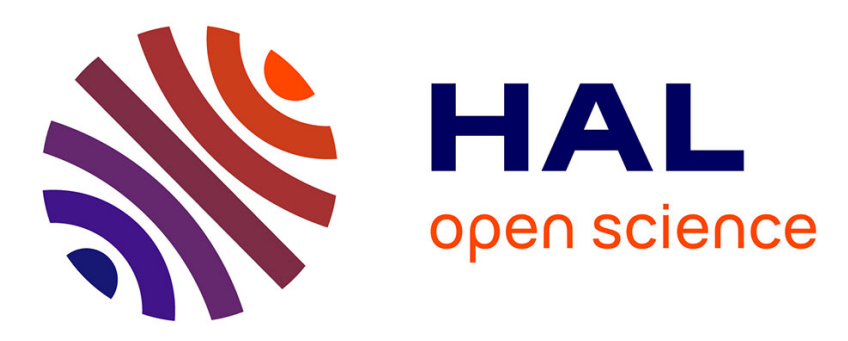

\title{
The kinetid structure of two oscarellid sponges (Class Homoscleromorpha) unveils plesiomorphies in kinetids of Homoscleromorpha-Calcarea lineage
}

Igor Pozdnyakov, Agniya Sokolova, Alexander Ereskovsky, Sergey Karpov

\section{- To cite this version:}

Igor Pozdnyakov, Agniya Sokolova, Alexander Ereskovsky, Sergey Karpov. The kinetid structure of two oscarellid sponges (Class Homoscleromorpha) unveils plesiomorphies in kinetids of Homoscleromorpha-Calcarea lineage. Invertebrate Biology, 2020, 139 (e12299), 10.1111/ivb.12299 . hal-02962150

\author{
HAL Id: hal-02962150 \\ https://hal.science/hal-02962150
}

Submitted on 4 Dec 2020

HAL is a multi-disciplinary open access archive for the deposit and dissemination of scientific research documents, whether they are published or not. The documents may come from teaching and research institutions in France or abroad, or from public or private research centers.
L'archive ouverte pluridisciplinaire HAL, est destinée au dépôt et à la diffusion de documents scientifiques de niveau recherche, publiés ou non, émanant des établissements d'enseignement et de recherche français ou étrangers, des laboratoires publics ou privés. 


\section{The kinetid structure of two Oscarellid sponges (class Homoscleromorpha) unveils}

plesiomorphies in kinetids of Homoscleromorpha-Calcarea lineage

Igor R. Pozdnyakov ${ }^{1 *}$, Agniya M. Sokolova ${ }^{3 *}$, Alexander V. Ereskovsky ${ }^{2,3,4}$, Sergey A. Karpov ${ }^{1,2}$ ${ }^{1}$ Zoological Institute of Russian Academy of Science, Universitetskaya emb. 1, St. Petersburg, 199034, Russia

${ }^{2}$ St. Petersburg State University, Biological Faculty, Universitetskaya emb. 7/9, St. Petersburg, 199034, Russia

${ }^{3}$ N. K. Koltzov Institute of Developmental Biology, Russian Academy of Sciences, Vavilova street 26, Moscow, 119334, Russia

${ }^{4}$ Aix Marseille University, Avignon Université, CNRS, IRD, IMBE, Marseille, France *equal contribution

corresponding author: I. Pozdnyakov,

Zoological Institute of Russian Academy of Science, Universitetskaya emb. 1, St. Petersburg, 199034, Russia

d_igor_po@yahoo.com

+79062469262 


\begin{abstract}
The structure of kinetid (flagellar/ciliary apparatus) is known to have a phylogenetic significance in sponges (phylum Porifera). Studying of this cell element could give the data for analysis of their evolutionary processes. The larval kinetid structure of the two closely-related species Oscarella lobularis and O. tuberculata (Homoscleromorpha, Oscarellidae) has been studied. Four previously recognized morphological regions in cinctoblastula of $O$. lobularis and O. tuberculata were confirmed: anterior pole, lateral zone, posterior-lateral cells (paracrystalline belt) and posterior pole. Kinetids of studied larval cells have two unique features: 1) position of the accessory centriole, which is arranged right under the kinetosome in apical-basal direction, and 2) inequality of the two fibrillar roots. The cells of paracrystalline belt have pear-shaped nuclei with paracrystalline inclusion connected to the roots of the kinetid. In the cells of other zones the nucleus is separated from the kinetid, and roots adjoin the Golgi apparatus. In studied species the position of kinetosome and nucleus coincides in larval cells and in their descendants - choanocytes. We propose the plesiomorphic state of next character set for the larval flagellated cells of the whole lineage "Calcarea+Homoscleromorpha": kinetosome-nucleus link, striated roots, simple basal foot, orthogonal centriole, long transition zone of the flagellum. The position of the centriole under kinetosome in homoscleromorph larvae and long fibrillar/microtubular bundle on the kinetosome in calcarean larvae might be an apomorphies of these groups.
\end{abstract}




\section{Introduction}

Sponges are the enigmatic group of animals that attract attention of the researchers for two reasons. At first, sponges are the candidates to be most basal group of Metazoa and therefore to be among the first animals on our planet (Pisani et al., 2015; Simion et al., 2017). At second, sponges are very specific group of animals, whose structure and biology differ substantially from other metazoans.

The subject of our interest is the kinetid (flagellar apparatus) of sponges. Studying of this cell element may give the data for analysis of evolutionary processes. This character is known to be relevant in taxonomy and phylogeny of unicellular eukaryotes (e. g., Yubuki \& Leander, 2013). Kinetid structure is quite diverse in sponge choanocytes (collar cells) and fitting the phylogenetic classification based on the genetic data (Pozdnyakov, \& Karpov, 2013, Pozdnyakov, \& Karpov, 2016a, Pozdnyakov, \& Karpov, 2016a, Pozdnyakov, Sokolova, Ereskovsky \& Karpov, 2018). Tracking the character states in different groups, we tried to reconstruct ancestral kinetid structure of the sponge choanocyte (Pozdnyakov, Sokolova, Ereskovsky \& Karpov, 2017).

But it has to be attended that sponges possess several types of flagellated cells and, accordingly, more than one type of kinetid. Sponges have biphasic bentho-pelagic life cycle with sessile adults and swimming larvae covered with cilia. The functions of flagellated cells in different stages are drastically different: cilia of larvae are responsible for moving through the water column, while flagella in choanocytes of adults establish water flow through the sponge. Therefore, the kinetid in choanocyte and larval cells could evolve in different ways. Herewith, the larval flagellated cells and choanocytes are not independent but linked to each other by morphogenetic processes. In many cases choanocytes of adult sponges are derived from the flagellated cells of larvae (Ereskovsky, 2010). In order to form the general picture of kinetid evolution in sponge flagellated cells, we have to collect more data on the kinetid structure of different sponge cells and recognize the plesiomorphic and apomorphic character states.

The object of the present study is larva of Homoscleromorpha, recently recognized (Gazave, Lapebie, Vacelet, Renard, \& Cardenas, 2012) sponge class. Homoscleromorphs combine the typical-sponge simple morphology with the highly organized histological structure bringing them together with Eumetazoa (Ereskovsky et al., 2009a). The choanocyte kinetid of Homoscleromorpha coincides with that in the class Calcarea (Pozdnyakov et. al., 2017). That seems not surprising if one takes into account close phylogenetic relationships of these classes (Philippe et al., 2009; Simion et al., 2017). The kinetid structure in larval cells of both calcarean sponges (Calcarea: Borojevic, 1969; Gallisian, 1983; Amano \& Hori, 1992; Gallisian \& Vacelet, 1992; Amano \& Hori, 2001; Ereskovsky \& Willenz, 2008; Lanna \& Klautau, 2012) and 
homoscleromorps are not fully studied (Boury-Esnault, Ereskovsky, Bézac \& Tokina, 2003; Maldonado \& Riesgo, 2008).

The structure of late Homoscleromorph larva (cinctoblastula) was detailly described previously (Boury-Esnault et al., 2003; De Caralt, Uriz, Ereskovsky, \& Wijffels, 2007; Ereskovsky, 2010; Ereskovsky et al., 2014; Ereskovsky, Konyukov \& Tokina, 2009; Ereskovsky, Tokina, Bézac \& Boury-Esnault, 2007; Maldonado \& Riesgo, 2008). Four morphological regions were recognized in its body: anterior pole, lateral zone, posterior-lateral cells bearing intranuclear paracrystalline inclusions (hereinafter referred to as the paracrystalline belt) and posterior pole (Boury-Esnault et al., 2003; Ereskovsky et al., 2007). This arrangement and appearance of larval cells were found in all investigated homoscleromorphs.

In this paper we investigate kinetid structure in larval cells of the two closely-related species: Oscarella lobularis Schmidt, 1862 and O. tuberculata Schmidt, 1868, representatives of the family Oscarellidae. This family is notable because one of its species clades (so-called "balibaloi group") has the kinetosome-nucleus connection in choanocytes, while in the second clade ("lobularis group", which includes both species studied here) nucleus and kinetosome are separated (Pozdnyakov et al., 2020). Therefore, the description of kinetid structure in larval cells of oscarellid sponges can shed some light on relation between the structure of choanocytes and larval flagellated cells in sponges.

\section{Materials and methods}

The sponges were collected by SCUBA diving in July-August 2009, 2015, and AugustSeptember 2016 in the Gulf of Lions, the Mediterranean Sea, at depths of 5-25 m. In the laboratory, larvae were released from maternal sponges by table-lamp illumination following dark adaptation. Larvae were transferred to sterile Petri dishes containing $30 \mathrm{ml}$ of seawater and maintained at $18^{\circ} \mathrm{C}$. Free-swimming larvae were collected with Pasteur pipette.

For transmission electron microscopy (TEM), two fixation methods were used: 1) one volume of $2.5 \%$ glutaraldehyde, four volumes of $0.2 \mathrm{M}$ cacodylate buffer ( $\mathrm{pH} 7.2-7.4$ ), and five volumes of seawater $(1.120 \mathrm{mOsm})$ and post-fixation in $2 \% \mathrm{OsO} 4$ in seawater, and 2) samples were prefixed in $1 \%$ OsO4 in $0.1 \mathrm{M}$ phosphate buffer $(\mathrm{pH} 7.2-7.4)$ for $10 \mathrm{~min}$ and fixed in $2.5 \%$ glutaraldehyde in $0.1 \mathrm{M}$ phosphate buffer $(1.120 \mathrm{mOsm})$ at room temperature for $1 \mathrm{~h}$. After fixation, samples were washed in $0.1 \mathrm{M}$ phosphate buffer ( $\mathrm{pH} 7.2-7.4$ ) and postfixed in $1 \%$ OsO4 in 0.1 M phosphate buffer (pH 7.2-7.4) for $1 \mathrm{~h}$ (Ereskovsky \& Boury-Esnault, 2002). Two methods of fixation were used in order to select the best. However, both types of fixation (with strict compliance to the protocol and osmolality) turned out to be good enough for the purpose of this work and we used the specimens fixed in both protocols. After finishing of all fixative 
processes the samples were dehydrated through a graded ethanol series, and embedded in Araldite. Thin sections were stained with uranyl acetate and lead citrate and were observed under a JEM 1400 electron microscopes equipped with an Olympus Veleta digital camera.

For scanning electron microscopy was used the first fixation method. After dehydration through a graded ethanol series, specimens were critical-point dried, mounted on a stub, coated with gold-palladium mixture and examined under a Hitachi S570 microscope.

\section{Results}

The cinctoblastula of Oscarella lobularis and $O$. tuberculata is covered by a columnar epithelium of polarized monociliary cells interspersed with single non-ciliary flask-shaped cells. We confirmed four morphological regions in its body: anterior pole, lateral zone, paracrystalline belt and posterior pole (Fig. $1 \mathrm{~A}$ ). In cells of the paracrystalline belt the kinetid structure markedly differs from that of other cells. Its nuclei are pear-shaped and connect to the fibrillar roots of the flagellar apparatus and the Golgi apparatus (Fig. 1 B, C, D). In other ciliary cells the nucleus is separated from the kinetid, and roots adjoin the Golgi apparatus only (Fig. 1 E, F, G). Nuclei in the above-mentioned zones are located on somewhat different level: in lateral zone (Fig. 1 E) they are basal, while in anterior (Fig. 1 F) and posterior (Fig. 1 G, Fig. 2 A) pole they often occupy almost middle position. Nevertheless, even in the rare cases when nucleus locates quite apically in these zones, it never connects to the kinetid root (Fig. 2 A). The flask-shaped cells, though lacking the flagellum, also have kinetid identical to that in lateral, posterior and anterior zones (Fig. $1 \mathrm{H}, \mathrm{h} 1$ ).

The accessory centriole occurs strictly perpendicular to the kinetosome and right under it (in apical-basal direction) (Fig. 1, D, E, F). The centriole is connected to the kinetosome by the bridge of fibrillar material (Fig. 2 E). Two fibrillar roots derive from the accessory centriole. The lateral root looks simply structured, and the posterior one is markedly striated (Fig. 1 C, D, Fig. 2 E, F, H). The kinetosome bears a basal foot, approximately $180 \mathrm{~nm}$ long (Fig. 1 B, Fig. 2 C). It consists of two or three stalks attached to the kinetosome and a large round distal head, which serves as a microtubule organizing center (MTOC) (Fig. 2 B, C, G). Numerous lateral microtubules radiate from the head in different directions. A bunch of microtubules also starts directly from the kinetosome surface without notable additional MTOCs (Fig. 2 C, D).

Nine thick transitional fibrils (=alar sheets) radiate from the distal end of the kinetosome (Fig. 2 C, D). An axial granule is attached by filaments to kinetosome microtubular triplets in distal part (Fig. $2 \mathrm{H} 2$ ).

The central microtubules of axoneme do not reach the cell surface, and the flagellar transition zone (area between the ends of the central microtubules and kinetosome) can be 
classified as of the long type. Above the transition zone the flagellum is filled with an electrondense material that forms so-called dark zone (Fig. 3 A).

We found no remarkable differences in kinetid structure of $O$. lobularis (Figs. 1-2) and $O$. tuberculata (Fig. 3). General structure of the flagellated larval cell kinetid can be described by the scheme given on the Fig. 3 E, F.

\section{Discussion}

Our results show that kinetid in larval cells of Homoscleromorpha has some peculiarities in comparison to other sponges. Firstly, we observed a stable orthogonal position of the accessory centriole arranged right under the kinetosome. It was probably such location that results in shift of the two fibrillar roots from the kinetosome to the centriole. This shift neither occurs in larval cells of other investigated sponges. In choanocytes of adult homoscleromorphs the sponges' typical centriole position (orthogonal and aside of kinetosome) recovers, but one root retains on the centriole (Pozdnyakov et al., 2020).

Second peculiar feature is inequality of the two roots. The basal root is notably striated, thick and longer while the apical is non-striated, thin and shorter. Such a combination of fibrillar roots has never been observed in any other sponges. In calcarean larvae the kinetosome of flagellated cells connects to the nucleus by two similar, stout, striated fibrillar roots (Borojevic, 1969; Amano \& Hori, 2001; Ereskovsky \& Willenz, 2008; Gallisian, 1983; Amano \& Hori, 1992; Gallisian \& Vacelet, 1992; Lanna \& Klautau, 2012). In demospongian larval cells fibrillar roots are non-striated, though in embryos of the chondrillid Halisarca dujardini Johnston, 1842 (Gonobobleva, 2007) and the poecilosclerid Lycopodina occidentalis (Lambe, 1893) (Riesgo et al., 2007) the fibrillar roots are striated on the early stage of development. Later that striation disappears.

In addition to the roots, sponge kinetid is anchored by the transverse cytoskeleton: lateral microtubules radiating from the microtubule organizing center (Amano \& Hori, 2001; Ereskovsky \& Willenz, 2008; Pozdnyakov et. al., 2017). The microtubular bundle in studied larvae start straight from the kinetosome itself. By this bundle, the kinetid of homoscleromorph larvae slightly resembles the kinetid of larvae in Calcarea, the sister lineage to Homoscleromorpha (Philippe et al., 2009; Wörheide et al., 2012; Simion et al., 2017). Calcarean larval cells include an additional dense and long cytoskeletal bundle on the kinetosome, which was described as the microtubular (Amano \& Hori, 2001; Borojevic, 1969; Ereskovsky \& Willenz, 2008; Lanna \& Klautau, 2012). However, the fixation quality does not allow unambiguous interpretation of its composition, and this bundle was also suggested to be filamentous (Efremova, Sukhodolskaya, \& Alekseeva, 1988). If the bundle of calcarean larvae 
has yet microtubular or mixed state, in can be the homologious to the one of homoscleromorph larvae. But if it still filamentous that the transverse cytoskeletons in kinetids of homoscleromorph and calcarean larvae consist of different elements and possible evolved independently.

In this study we confirm the known complex structure of cinctoblastula of homoscleromorph sponges with three types of flagellated cells recognized: the antero-lateral, postero-lateral and posterior (Boury-Esnault et al., 2003; Ereskovsky, 2010). In studied larvae of $O$. lobularis and $O$. tuberculata nuclei position is slightly different than in the previously proposed scheme (BouryEsnault et al., 2003). In postero-lateral cells (paracrystalline belt cells) the nucleus is definitely linked with the kinetosome, but other cells never have such connection and their roots always contact with the Golgi apparatus only (even if the nucleus takes place not far from the kinetosome). Also, the nuclei position in anterior and posterior regions is a bit more apical than in lateral cells.

The complex structure of homoscleromorph larva forms only at late developmental stages. But flagellum emerges at the earlier stage of coeloblastula (Boury-Esnault et al., 2003), and we have no complete data on kinetid transformation during embryo development. There are also no data on the kinetid's fate after larval settlement. Homoscleromorpha are the only sponges whose larval epithelium retain the flagella during metamorphosis (Ereskovsky et al. 2007). Thus, the kinetid of larval cells is to maintain too. However, the peculiar features of kinetid in larval cells (centriole position and roots structure) are not reproduced in choanocytes of the studied species (Pozdnyakov et al., 2020). Some kinetid transformations therefore take place.

$O$. lobularis and $O$. tuberculata larvae include both cells with and without the kinetosomenucleus connection, while choanocytes of these species has no such connection (Pozdnyakov et al., 2020). Choanocytes of Homoscleromorpha derive mainly from anterior and lateral cells of larval epithelium (Ereskovsky et al., 2007; Ereskovsky et al., 2009; Ereskovsky, 2010), i. e. the cells with the independent nucleus and kinetosome. Thus, in studied species the position of kinetosome and nucleus coincides in larval cells and in their descendants - choanocytes (Fig. 4 A). It is intriguing whether homoscleromorphs with kinetosome-nucleus connection in choanocytes (Plakinidae and some Oscarellidae) inherit it from larval cells or not (Fig. 4 B). But we have only partial data on such homoscleromorphs' larvae. Their cinctoblastulae are known to include the same three types of covering cells (Boury-Esnault et al., 2003), but we have not precise understanding of their kinetid's diversity (Boury-Esnault et al., 2003; De Caralt et al., 2007; Ereskovsky et al., 2009; Maldonado \& Riesgo, 2008).

Comparing to homoscleromorphs, calcarean sponges has the nucleus, kinetosome and Golgi apparatus arranged more uniform. In both calcarean subclasses, Calcinea and Calcaronea, the 
nucleus of larval flagellated cells is always apical and pear-shaped. It connects to the kinetosome by striated fibrillar roots (Borojevic, 1969; Amano \& Hori, 2001; Ereskovsky \& Willenz, 2008; Gallisian, 1983; Amano \& Hori, 1992; Gallisian \& Vacelet, 1992; Lanna \& Klautau, 2012). But choanocyte kinetids in these two groups differ: Calcinea has the kinetid separated from the basal roundish nucleus (Amano \& Hori, 2001), while Calcaronea maintains the pear-shaped nucleus clearly associated with the kinetid (Pozdnyakov \& Karpov, 2013). The fate of flagellated cells in Calcarea differs from that in Homoscleromorpha: their flagellum resorbs and cells dedifferentiate during metamorphosis (Amano \& Hori, 2001; Ereskovsky \& Wilenz, 2008). Thus, in Calcarea the kinetid organization in choanocyte kinetid structures possibly does not depend on larval kinetid (Fig. 4 C, D).

The hypothesis about plesiomorphic state of kinetosome-nucleus connection was put forward by Ereskovsky and Willenz (2008) for calcarean larvae. Since this character is present in some cells of all known homoscleromorph larvae, we can extend the assumption about its plesiomorphy to the whole lineage "Calcarea+Homoscleromorpha". The set of plesiomorphies of larval cell kinetid for this lineage is to include also the striated roots, long transition zone of the flagellum, simple basal foot, orthogonal centriole; these features coincides in representatives of both classes (Borojevic, 1969; Amano \& Hori, 2001; Ereskovsky \& Willenz, 2008; Gallisian, 1983; Amano \& Hori, 1992; Gallisian \& Vacelet, 1992; Lanna \& Klautau, 2012). At this point, position of the centriole under kinetosome in homoscleromorph larvae and long fibrillar/microtubular bundle on the kinetosome in calcarean larvae might be an apomorphies of these groups. However the long bundle of the calcarean larvae might have the homology in the homoscleromorph larvae. It could be clarified after exact study of its fibrillar or microtubular nature.

\section{Acknowledgements}

The research was supported by the Russian Foundation for Basic Research (projects nos. 1804-01314 and 19-34-90084). IP was supported by the ZIN RAS research project AAAA-A19119031200042-9 The work of AS was conducted under the IDB RAS GBRP № 0108-20180002. SK was supported by the ZIN RAS research project AAAA-A19-119020690109-2. We thank Research Resource Center for Molecular and Cell Technologies (RRC MCT) at St. Petersburg State University for access to the EM facilities and the Morphology Service of the Mediterranean Institute of Marine and Terrestrial Biodiversity and Ecology (IMBE).

\section{References}


Amano, S., \& Hori, I. (2001). Metamorphosis of coeloblastula performed by multipotential larval flagellated cells in the calcareous sponge Leucosolenia laxa. Biological Bulletin, 200(1), 20-32. https://doi.org/10.2307/1543082

Amano, S., \& Hori, I. (1992). Metamorphosis of calcareous sponges I. Ultrastructure of freeswimming larvae. Invertebrate Reproduction and Development, 21(2), 81-90. https://doi.org/10.1080/07924259.1992.9672223

Borojevic, R. (1969). Etude du développement et de la differentiation cellulaire d'éponges calcaires Calcinées (genres Clathrina et Ascandra). Ann Embryol Morph, 2, 15-36.

Boury-Esnault, N., Ereskovsky, A., Bézac, C., \& Tokina, D. (2003). Larval development in the Homoscleromorpha (Porifera, Demospongiae). Invertebrate Biology, 122(3), 187-202. https://doi.org/10.1111/j.1744-7410.2003.tb00084.x

De Caralt, S., Uriz, M. J., Ereskovsky, A. V., \& Wijffels, R. H. (2007). Embryo development of Corticium candelabrum (Demospongiae: Homosclerophorida). Invertebrate Biology, 126(3), 211-219. https://doi.org/10.1111/j.1744-7410.2007.00091.x

Efremova, S., Sukhodolskaya, A., \& Alekseeva, N. (1988). The different structure of kinetosome rootlet systems in flagellated cells of the larvae and the choanocytes of sponges. In Modern and Perspective Investigations. Porifera and Cnidaria. (pp. 22-23). Leningrad: USSR Academy of Sciences, Zoological institute.

Ereskovsky, A. V. (2010). The Comparative Embryology of Sponges. Heidelberg, London, New York: Springer Science+Business Media.

Ereskovsky, A. V, Borchiellini C., Gazave, E., Ivanisevic, J., Lapebie, P., Perez, T., Renard, E., \& Vacelet, J. (2009). The Homoscleromorph sponge Oscarella lobularis, a promising sponge model in evolutionary and developmental biology. BioEssays, 31(1), 89-97. https://doi.org/10.1002/bies.080058

Ereskovsky, A. V., \& Boury-Esnault, N. (2002). Cleavage pattern in Oscarella species (Porifera, Demospongiae, Homoscleromorpha): transmission of maternal cells and symbiotic bacteria. Journal of Natural History, 36, 1761-1775. https://doi.org/10.1080/00222930110069050

Ereskovsky, A. V, Konyukov, P. Y., \& Tokina, D. B. (2009). Morphogenesis accompanying larval metamorphosis in Plakina trilopha (Porifera, Homoscleromorpha). Zoomorphology, 129(1), 21-31. https://doi.org/10.1007/s00435-009-0097-5

Ereskovsky, A.V., Lavrov, D.V., \& Willenz, P. (2014). Five New Species of Homoscleromorpha (Porifera) from the Caribbean Sea and re-description of Plakina jamaicensis. Journal of the Marine Biological Association of the United Kingdom, 94(2), 285-307, doi:10.1017/S0025315413000295. 
Ereskovsky, A. V, Tokina, D. B., Bézac, C., \& Boury-Esnault, N. (2007). Metamorphosis of Cinctoblastula Larvae (Homoscleromorpha, Porifera). Journal of Morphology, 528, 518-528. https://doi.org/10.1002/jmor

Ereskovsky, A. V., \& Willenz, P. (2008). Larval development in Guancha arnesenae (Porifera, Calcispongiae, Calcinea). Zoomorphology, 127, 175-187. https://doi.org/10.1007/s00435-008-0061-9

Gallissian, M.-F. (1983). Etude ultrastructurale du developpement embryonnaire chez Grantia compressa F (Porifera, Calcarea). Archives d'Anatomie Microscopique, 72(1), 59-75.

Gallissian, M.-F., \& Vacelet, J. (1992). Ultrastructure of the oocyte and embryo of the calcified sponge, Petrobiona massiliana (Porifera, Calcarea). Zoomorphology, 112, 133-141.

Gazave, E., Lapebie P., Vacelet, J., Renard, E., \& Cardenas, P. (2012). No longer Demospongiae: Homoscleromorpha formal nomination as a fourth class of Porifera. Hydrobiologia, 687, 3-10. https://doi.org/10.1007/s10750-011-0842-х

Gonobobleva, E.L. (2007). Basal apparatus formation in external flagellated cells of Halisarca dujardini larvae (Demospongiae: Halisarcida) in the course of embryonic development. In: Custódio MR, Lôbo-Hajdu G, Hajdu E, Muricy G (eds). Porifera Research: Biodiversity, Innovation and Sustainability (pp 345-351). Museu Nacional, Rio de Janeiro 28.

Gonobobleva, E., \& Maldonado, M. (2009). Choanocyte Ultrastructure in Halisarca dujardini (Demospongiae, Halisarcida). Journal of Morphology, 270(5), 615-27. https://doi.org/10.1002/jmor.10709

Lanna, E., \& Klautau, M. (2012). Embryogenesis and larval ultrastructure in Paraleucilla magna (Calcarea, Calcaronea), with remarks on the epilarval trophocyte epithelium ('placental membrane'). Zoomorphology, 131, 277-292. https://doi.org/10.1007/s00435-012-0160-5

Maldonado, M., \& Riesgo, A. (2008). Reproductive output in a Mediterranean population of the homosclerophorid Corticium candelabrum (Porifera, Demospongiae), with notes on the ultrastructure and behavior of the larva. Marine Ecology, 29(2), 298-316. https://doi.org/10.1111/j.1439-0485.2008.00244.x

Philippe H., Derelle R., Lopez P., Pick K., Borchiellini C., Boury-Esnault N., Vacelet J., Renard E., Houliston E., Quéinnec E., Da Silva C., Wincker P., Le Guyader H, Leys S., Jackson D.J., Schreiber F., Erpenbeck D., Morgenstern B., Wörheide G., \& Manuel M. (2009). Phylogenomics Revives Traditional Views on Deep Animal Relationships. Current Biology, 19, 706-712. https://doi.org/10.1016/j.cub.2009.02.052 
Pisani, D., Pett, W., Dohrmann, M., Feuda, R., Rota-Stabelli, O., Philippe, H., Lartillot, N., \& Wörheide G., (2015). Genomic data do not support comb jellies as the sister group to all other animals. PNAS, 112(50), 15402-15407. https://doi.org/10.1073/pnas.1518127112

Pozdnyakov, I. R. \& Karpov, S. A. (2013). Flagellar apparatus structure of choanocyte in Sycon sp. and its significance for phylogeny of Porifera. Zoomorphology, 132, 351-357. https://doi.org/10.1007/s00435-013-0193-4

Pozdnyakov, I. R. \& Karpov, S. A. (2016 a). Structure of choanocyte's kinetid in sponge Haliclona sp. (Demospongiae, Haplosclerida) and its implication for taxonomy and phylogeny of Demospongiae. Biology Bulletin of Russian Academy of Science, 43, 595-601. https://doi.org/10.1134/S1062359016070153

Pozdnyakov, I. R. \& Karpov, S. A. (2016 b). Kinetid structure in choanocytes of sponges (Heteroscleromorpha), toward the ancestral kinetid of Demospongiae. Journal of Morphology, 277, 925-934. https://doi.org/10.1002/jmor.20546

Pozdnyakov, I. R., Sokolova, A. M., Ereskovsky, A. V. \& Karpov, S. A. (2017). Kinetid structure of choanoflagellates and choanocytes of sponges does not support their close relationship. Protistology, 11, 248-264. https://doi.org/10.21685/1680-0826-2017-11-4-6

Pozdnyakov, I. R., Sokolova, A. M., Ereskovsky, A. V., \& Karpov, S.A. (2018). Kinetid structure in sponge choanocytes of Spongillida in the light of evolutionary relationships within Demospongiae. Zoological Journal of the Linnean Society, 184, 255-272.

https://doi.org/10.1093/zoolinnean/zlx109

Pozdnyakov, I., Sokolova, A., Karpov, S., Ruiz, C., Pérez, T., Ekimova, I., \& Ereskovsky, A. (2020). Morphological variability of choanocyte kinetids supports a novel systematic division within Oscarellidae (Porifera, Homoscleromorpha). Journal of Zoological Systematics and Evolutionary Research. In press.

Riesgo, A., Taylor, C., \& Leys. S.P. (2007). Reproduction in a carnivorous sponge: the significance of the absence of an aquiferous system to the sponge body plan. Evolution \& Development, 9, 618-631. doi: 10.1111/j.1525-142X.2007.00200.x

Simion, P., Philippe, H., Baurain, D., Jager, M., Richter, D. J., Di Franco, A., Roure, B., Satoh, N., Quéinnec, É., Ereskovsky, A., Lapébie, P., Corre, E., Delsuc, F., King, N., Wörheide, G., \& Manuel, M. (2017). A Large and Consistent Phylogenomic Dataset Supports Sponges as the Sister Group to All Other Animals. Current Biology, 27(7), 958-967. https://doi.org/10.1016/j.cub.2017.02.031

Sokolova, A. M., Pozdnyakov, I. R., Ereskovsky, A. V., \& Karpov S. A. (2019). Kinetid structure in larval and adult stages of the demosponges Haliclona aquaeductus (Haplosclerida) 
and Halichondria panicea (Suberitida). Zoomorphology, 138, 171-184.

https://doi.org/10.1007/s00435-019-00437-5

Wörheide, G., Dohrmann, M., Erpenbeck, D., Larroux, C., Maldonado, M., Voigt, O., Borchiellini C., \& Lavrov, D. V. (2012). Deep Phylogeny and Evolution of Sponges (Phylum Porifera). Advances in Marine Biology, 61, 1-78. https://doi.org/10.1016/B978-0-12-387787$1.00007-6$

Yubuki, N., \& Leander, B. S. (2013). Evolution of microtubule organizing centers across the tree of eukaryotes. The Plant Journal, 75, 230-244. https://doi.org/10.1111/tpj.12145 


\section{Figure legends}

Fig. 1. Structure of Oscarella lobularis larva. A - general view of Oscarella lobularis larva and sectioned larva in SEM, B-H - ultrathin sections (TEM) of different kinds of larva cells. BD - cells of the paracrystalline, E - lateral cell, F - posterior cell, G - anterior cell, H - flaskshaped cell, h1 - magnified kinetid zone of the same cell but in the next section of a series (kinetosome, centriole, roots and basal foot are seen).

Abbreviations: A - anterior pole, $\mathrm{L}$ - lateral zone, $\mathrm{B}$ - belt zone, $\mathrm{P}$ - posterior pole; ac accessory centriole, bf - basal foot, fl - flagellum, Ga - Golgi apparatus, ipi - intranuclear paracrystalline inclusions, $\mathrm{k}$ - kinetosome, $\mathrm{N}$ - nucleus, $\mathrm{r}$ - root.

Fig. 2. Kinetid ultrastructure of Oscarella lobularis. A - general view of posterior cell of Oscarella lobularis larva at longitudinal section, B-F - details of kinetid structure, $\mathrm{G}$ - the basal foot (magnified), H1-H3 - a series of the same cell.

Abbreviations: ac - accessory centriole, ag - axial granule, bf - nasal foot, Ga - Golgi apparatus, $\mathrm{h}$ - head of basal foot; lmt - lateral microtubules, mct - microtubules, fb - fibrillar bridge, fr - fibrillar root, $\mathrm{k}$ - kinetosome, sr - striated root, st - stalk of basal foot, tf -transitional fibrils.

Fig. 3. Kinetid structure of Oscarella tuberculata. A - longitudinal sections of belt cells, BD - longitudinal sections of lateral cells, E - scheme of kinetid structure in lateral, anterior and posterior cells of the studied larvae, F - scheme of kinetid structure in the paracrystalline belt in both species.

Abbreviations: ac - accessory centriole, ag - axial granule, bf - basal foot, $\mathrm{cm}$ - central microtubules, $\mathrm{dz}$ - dark zone, fb - fibrillar bridge, fr - fibrillar root, $\mathrm{Ga}$ - Golgi apparatus, ipi intranuclear paracrystalline inclusion, $\mathrm{lmt}$ - lateral microtubules, $\mathrm{n}$ - nucleus, $\mathrm{sr}$ - striated root, $\mathrm{tf}$ - transitional fibrils.

Fig. 4. The arrangement scheme of the nucleus and kinetid in flagellated cells of Homoscleromorpha and Calcarea.

A - Homoscleromorpha without the kinetosome-nucleus connection in choanocytes (Oscarellidae of "lobularis group"); B - Homoscleromorpha with the kinetosome-nucleus connection in choanocytes (Plakinidae, Oscarellidae of "balibaloi group"); C - Calcarea without the kinetosome-nucleus connection in choanocytes (Calcinea); D - Calcarea with the kinetosome-nucleus connection in choanocytes (Calcaronea).

Abbreviations: al lfc - antero-lateral larval flagellated cells, ambl - amphyblastula, ch choanocyte, coebl - coeloblastula, cibl - cynctoblastula, lfc -larval flagellated cells, pl lfc postero-lateral larval flagellated cells (cells of "paracrystalline belt"). 